\title{
Criminal Victimisation and Depression in the Czech Republic*
}

\author{
LEE MICHAEL JOHNSON* \\ JOSEPH HRABA \\ FREDERICK O. LORENZ \\ lowa State University, Ames, IA, USA
}

\begin{abstract}
Since the fall of communism in 1989, criminal victimisation has become an issue in the Czech Republic, and research indicates that it is a stressful experience. The relationship between criminal victimisation and depression was examined by adding fear of crime, protection against crime, avoidance of crime, mastery over one's life, social support, and trust in government (as well as socio-demographic controls) to successive regression equations. A total of 703 Czech households in the second of a three-wave (1994-1996) panel study were studied. For men, the total and direct effects of criminal victimisation on depression were significant. However, the relation of men's fear of crime and depression was mediated by avoidance. For women, criminal victimisation was not related to depression. The relation of women's fear of crime and depression was mediated by mastery. Interpretations of these results are grounded in the different relevance criminal victimisation has for the well-being of men and women.
\end{abstract}

Czech Sociological Review, 2000, Vol. 8 (No. 2: 195-209)

Since the fall of communism in 1989, the issue of criminal victimisation has become a public concern in the Czech Republic. American research shows that criminal victimisation has real consequences, such as the diminished psychological well-being of victims, and it can be assumed that it poses a threat to the well-being of Czech citizens also. In this analysis, criminal victimisation in the Czech Republic is examined within the theoretical framework of the stress-distress perspective. The analysis begins with a brief discussion of rising crime during the period of the Czech transformation prior to 1994.

\section{Rising Crime in the Czech Republic}

Since the fall of communism in 1989 crime rates have been rising in former Czechoslovakia. The 1992 International Crime Survey (ICS) revealed that of all Czechoslovak respondents in the survey, $10.9 \%$ reported having been a burglary victim, $22 \%$ reported having had personal property stolen, and $9.4 \%$ reported that they had been the victims of an assault - the second highest proportion of assault victims reported for post-communist countries [Valkova 1993]. In addition, among Czechoslovak respondents in the 1992 ICS, $9 \%$ of the women reported having been the victims of sexual offences, and almost $44 \%$ of car owners in the survey had experienced car vandalism [Siemaszko 1993]. In Prague, Buriánek [1994] found an increase in types of crime new to the Czech Republic, such as drug dealing, economic crime and organised crime. The 1992 ICS also reported that $33.4 \%$ of Czech respondents felt 'a bit unsafe' and 10.5\% felt 'very unsafe' when walking alone in their area at night [Valkova 1993].

\footnotetext{
*) NIMH (Grant 50369) and a NATO Collaborative Research Grant supported this research. *) Direct any correspondence to Lee Michael Johnson, Department of Sociology, Iowa State University, 107 East Hall, Ames, IA 50011-1070, USA, phone +1-515-294-8012.
} 
While the Czech public's concern with crime has increased, its faith in the state to control it has decreased. In a 1992 national poll, $86 \%$ of Czech respondents reported that they were dissatisfied with police [Hraba et al. 1996]. The 1992 ICS showed that 55.4\% of respondents were dissatisfied with the way police handled reported crime, and $32.4 \%$ thought the police do a bad job of patrolling streets [Valkova 1993]. The 1992 ICS also showed a lack of faith in police as the main reason given in former Czechoslovakia for not reporting car vandalism [Siemaszko 1993]. Hraba et al. [1998] found a perceived increased risk of crime among Czechs that was due to a lack of trust in government as well as criminal victimisation.

One reason for the rise in crime is that economic motives for crime have increased in the Czech Republic. With the transformation, the state no longer guarantees employment and public entitlements have diminished. Earnings inequality began to increase in 1990, with higher incomes rising and diverging from others [Rondinelli 1994; Večerník 1995, 1996a], who in turn have experienced declining income, economic insecurity, and subjective poverty [Matěju and Řeháková 1996; Musil 1992; Večerník 1996b]. These factors have been associated with arrest rates in the United States [LaFree and Drass 1996] and may also serve as economic motives for crime in the Czech Republic.

\section{Criminal Victimisation in the Stress-Distress Perspective}

Consistent with both criminological and stress-distress research, criminal victimisation is posited to be a stressor that can produce depressive symptoms in victims [Coyne and Downey 1991; Hraba et al. 1999; Kilpatrick et al. 1985; Mawby and Walkate 1994; Norris and Kaniasty 1994; Proulx et al. 1995]. The effect of criminal victimisation on depression may depend, however, on the emotional reactions of victims to victimisation. Increased fear of crime is one of these reactions. In criminology, fear of crime is defined as a feeling of dread about being victimised by crime [Ferraro 1995; Garofalo 1981; Giles-Sims 1984; LaGrange and Ferraro 1989; Miethe and Lee 1984; Taylor and Hale 1986], and it is considered to be a consequence of crime itself [Giles-Sims 1984; Ferraro 1995; Garofalo 1981; Norris and Kaniasty 1994; Roundtree and Land 1996; Thompson and Norris 1992]. It is also seen as a cause of psychological distress in stress-distress research [Ross 1993]. This analysis will test whether Czech victims become depressed in direct response to criminal victimisation, or whether they must first fear it (interpreting it as a threat to personal well-being) in order to become depressed.

The effect of criminal victimisation may also depend on victims' behavioural responses to victimisation and fear of crime. These reactions can be stress-coping strategies. Approach strategies are those intended to increase one's resistance to stress, and avoidance strategies are those intended to reduce the occasions when one is confronted by stress. Approach strategies appear to have more power in reducing distress [Coyne and Downey 1991; Elder 1974; Lorenz et al. 1996]. The restrictions to personal freedom associated with avoidance strategies may have a negative effect on people's psychological well-being, thus reducing their effectiveness in reducing distress [Hraba et al. 1999]. Similarly, criminologists are interested in protection and avoidance as reactions to crime. Protection strategies are those which are intended to increase a person's ability to resist criminal victimisation - learning self-defence techniques, for example. Avoidance strategies, on the other hand, are those which are intended to reduce the opportunities for others to offend - not going out after dark or into certain neighbourhoods, for example [DuBow et al. 1979; Garofalo 1981; Liska and Warner 1991; Roundtree and Land 1996]. 
In this analysis, protection from criminal victimisation is considered to be an approach-coping strategy, while avoidance of criminal victimisation is, obviously, an avoidance-coping strategy. Norris and Kaniasty [1994] found that protective action reduces the effects of criminal victimisation on distress, while Proulx et al. [1995] found the use of 'escapist' coping strategies to be associated with higher levels of distress. Hraba et al. [1999] found that protection decreased depression among Czech men, while avoidance increased their depression and anxiety.

The effect of criminal victimisation on distress also depends on the personal and social resources victims have for coping with the stress of victimisation. In stress-distress studies, a sense of personal control (mastery) has been identified as one of the most important psychological resources one can have in handling stress [Aneshensel 1992; Mirowsky and Ross 1989; Pearlin et al. 1981; Taylor and Aspinwall 1996; Turner and Roszell 1994]. People with a high sense of mastery believe they have a high degree of power over themselves and their environment [Turner and Roszell 1994]. Social support can also reduce psychological distress [Coyne and Downey 1991; Ensel and Lin 1991; Sarason, Pierce, and Sarason 1994; Taylor and Aspinwall 1996]. Social support may come in the form of advice, tangible aid (money, for example), and reassurances of selfesteem [Taylor and Aspinwall 1996]. It is reasoned in this analysis that Czech victims who believe they can count on others for support should suffer less depression from criminal victimisation. Also, trust in government is added to this analysis as another social resource - a state resource - that may be used to cope with criminal victimisation. Since the beginning of the transformation, some surveys have indicated that the trust Czechs have in their government has been declining [Hraba et al. 1998; Rose 1994]. It is reasoned here that Czech crime victims who are still able to trust authorities to protect them from future victimisation should suffer less depression.

Since research in the United States [Mirowsky and Ross 1989; Pearlin 1989; Turner, Wheaton, and Lloyd 1995; Williams 1990] and the Czech Republic [Hraba et al. 1999; Hraba, Lorenz, and Pechačová 1997; Hraba et al. 1994] shows that depression levels vary according to age and social status, the control variables of age, education, marital status, income, and rural/urban residence of respondents are included here. Research in the US also reveals sex differences in reported distress [Elder et al. 1994; Friedemann and Webb 1995], and sex differences in distress were indeed found in the Czech Republic [Hraba et al. 1994; Hraba, Lorenz, and Lee 1996]. Males and females are here analysed separately because most of the data are taken from paired husbands and wives.

This analysis presents an empirical test of the argument that criminal victimisation is related to depression symptoms directly and indirectly through fear of crime, protection, avoidance, mastery, social support, and trust in government. Multiple regression analysis is used to test this relationship. Criminal victimisation is included as an exogenous variable, depression symptoms make up the outcome variable, and the other six variables are considered as possible mediating variables. The variables are then examined with a series of eight equations. After regressing depression symptoms on criminal victimisation, control variables, fear of crime, and personal and social resource variables are added in successive equations. 


\section{Methods}

Sample

The sample consists of two waves of data collected in the Czech Republic in 1994 and in 1995. The original sample was selected from a panel of 4,000 households contacted periodically by the Czech Census Bureau Division of Family Budgets. Families were informed about the research goals and asked to participate in a survey during the Bureau's interviews in autumn 1993. Those who agreed to participate returned a signed consent form to the Bureau. From among them the Bureau randomly selected 774 families, with roughly equal numbers from rural and urban areas, and mailed them questionnaires. The Bureau detected no selection bias, but the panel is a quota sample based on rural/urban residence and is not necessarily representative of the country. A total of 740 families $(96 \%)$ returned the questionnaires. The first wave sample is comprised of 577 husbands and wives, 146 single female-headed households, and 17 single male-headed households. In the second wave, $703(95 \%)$ of the 740 families from the first wave returned questionnaires. The second wave sample is comprised of 546 husbands and wives, 139 single female-headed households, and 16 single male-headed households. In both waves, spouses answered separate questionnaires and returned them in separate envelopes. They were asked not to consult each other when answering them. This analysis is based on 535 men and 639 women who provided complete data in both waves.

\section{Measures}

Criminal Victimisation. Three items were summed to create an index of criminal victimisation. Respondents in 1995 were asked: "During the last year, 1) were you robbed, assaulted or mugged? 2) did anyone break into or somehow illegally get into your apartment or home? and 3) did anyone take something directly from you by use of forcesuch as a hold-up, mugging, or threat?" Responses to these three items are coded as "Yes" = 1 and "No" = 0 . Victimisation was reported $11.2 \%$ of the men and $10.2 \%$ of the women.

Age. Respondents in 1995 were asked: "How old are you?" The respondents' ages are coded in their years of age. Men's ages ranged from 21 to 81, with a mean of 44.4, and women's ages ranged from 20 to 85 , with a mean of 42.11 .

Education. Respondents' education (in 1994) is coded as the level of completed education. Respondents chose from: (1) elementary (2) vocational training (3) secondary school (4) college (5) university (6) post-graduate degree (CSc. or DrSc.).

Marital Status. Respondents' marital status (in 1995) was coded as 1 = single (never married, divorced/separated, and widowed) and $2=$ married (including cohabiting partners). A total of $97 \%$ of the men and $80.3 \%$ of the women reported being married.

Urban/Rural Residence. Residence is defined as the population size of the locality in which the respondent lives. Respondents' residences (in 1995) are coded as $0=$ rural (5,000 or less inhabitants) and $1=$ urban (over 5,000). Of all respondents, $52.7 \%$ of men live in rural areas and $47.3 \%$ live in urban areas, while $48.8 \%$ of women live in rural areas and $51.2 \%$ live in urban areas.

Income. Income is coded as the amount of money a person receives from any source per year. Respondents (in 1995) wrote their income in one thousand units of Czech crowns. The median incomes are 73,000 CZK for men and 53,500 CZK for women, both with a 
range of 0 to $450,000 \mathrm{CZK}$. A logarithmic transformation is used on income to adjust for skewness (2.584 for men and 2.71 for women).

Fear of Crime. Two items were summed to create an index of fear of crime. Respondents in 1995 were asked: 1) "Is there any area right around here - that is, within a kilometre or two - where you would be afraid to walk alone at night?" ("yes" =1, "no" = 0, "don't know" =0) and 2) "Compared with last year, do you personally feel more uneasy on the streets, less uneasy or not much different?" (Responses are coded as: "more uneasy" = 1 , "less uneasy" $=0$, "not much different" $=0$, "not sure" $=0$ ). The first item has been routinely included as a measure of fear of crime in American surveys [cf. Warr 1994]. The second item is used to measure Czech respondents' emotions about being in public during a time of rising contact crime. The mean scores are 0.54 for men and 1.13 for women.

Protection. Two items were summed to create an index of protection. Respondents in 1995 were asked: 1) "Has the fear of crime caused you to install a home security system?" and 2) "Has the fear of crime caused you to install an automobile security system?" ("yes" = 1, "no" =0). These items, especially the second, are more likely to measure protective action against property crime. However, the measure of victimisation used in this analysis is concerned with crime that is more dangerous to personal safety. A 'crossover effect' from property protection to personal protection will be tested for here. It is possible that actions taken to protect one's property also include actions taken to protect one's person [Hraba et al. 1999]. The mean protection scores are 0.27 for men and 0.21 for women. Protective behaviour was indicated by $21.8 \%$ of the men and $18.5 \%$ of the women.

Avoidance. Three items were summed to create an index of avoidance. Respondents in 1995 were asked: "Has the fear of crime caused you to... 1) limit the places or times that you go shopping? 2) limit the places or times that you work? and 3) limit the places that you will go by yourself?" ("yes" = 1, "no" =0). Fear of crime was specified in these questions to avoid responses based on limiting these activities for other reasons such as physical disability or external constraints (such as business hours) [Hraba et al. 1997]. The mean avoidance scores are 0.27 for men and 0.66 for women. Avoidance action was taken by $20.1 \%$ of the men and $50.5 \%$ of the women.

Mastery. Consistent with Pearlin et al. [1981], mastery is defined as the perception of control over one's life. Seven items were summed to create an index of mastery. In 1994, respondents indicated how strongly they agreed or disagreed with seven statements about themselves. Sample statements are: "There really is no way I can solve some of the problems I have" and "I can do just about anything I really set my mind to". Responses are coded as: "strongly agree" $=1$, "agree" $=2$, "uncertain or mixed" $=3$, "disagree" $=4$, "strongly disagree" $=5$. The $\alpha=0.75$ for men and $\alpha=0.74$ for women. The mean mastery scores are 25.16 for men (range $=14$ to 35 ) and 24.19 for women (range $=8$ to 35 ).

Social Support. Twelve items were summed to create an index for social support. Respondents in 1995 were asked: "Thinking about relatives, neighbours, close friends or acquaintances other than your spouse or children, how true is each of these statements for you?..." The statements indicated three types of social support: appraised, tangible, and that of belonging. Samples of each are: "Other than my husband or children, there are several people that I trust to help solve my problems" (appraised); "If I needed an emergency loan of 1000 crowns, there is someone (friend, neighbour, other relatives, or acquaintance) I could get it from" (tangible), and "My friends really care about me" 
(belonging). Responses are coded as: "definitely true" $=1$, "probably true" $=2$, "probably false" $=3$, "definitely false" $=4$. The $\alpha=0.78$ for men and $\alpha=0.77$ for women. The mean social support scores are 21.18 for men (range $=22$ to 48 ) and 20.68 for women (range $=19$ to 48$)$.

Trust in Government. Two items were summed to create an index of trust in government. Respondents in 1994 were asked: 1) "To what extent do you trust the current government to take actions necessary to control crime?" ("do not trust at all" = 1, "to some extent" = 2 , and "to a great extent" = 3) and 2) "Think about how the changes in government have directly affected you since 1989. Would you say you experience more, the same, or less danger from crime? " ("more" = 1, "same" = 2, "less" = 3). The mean trust in government scores are 2.84 for men and 2.88 for women.

Depression. Ten items adapted from Derogatis [1983] SCL-90 were summed to create an index of depression. Respondents in 1995 were asked about depressive symptoms they experienced "during the past week", such as "loss of sexual interest", "feeling low in energy or slowed down", "crying easily", "feeling lonely", "trouble concentrating", and "feelings of worthlessness". Responses are coded as: "not at all" = 0 , "a little bit" = 1 , "moderate" $=2$, "quite a bit" $=3$, "extremely" $=4$. The $\alpha=0.85$ for both men and women. The mean depression scores are 4.48 for men (range $=0$ to 31 ) and 7.10 for women (range $=0$ to 33 ).

\section{Results}

Tables 1 (men) and 2 (women) contain the regression coefficients (with standard errors and significance) from eight successive equations. In Equation 1, depressive symptoms are regressed on criminal victimisation. Criminal victimisation is significantly and positively related to depressive symptoms for men $(\beta=0.147)$ but not for women $(\beta=0.065)$. With Equation 2, (Tables 1 and 2) the age, education, marital status, income, and ru$\mathrm{ral} /$ urban residence of respondents are added as a set of controls. The net of controls shows that criminal victimisation is significantly related to depressive symptoms for men ( $\beta=0.143)$ but not for women $(\beta=0.059)$. Among the controls, age is related to men's depressive symptoms $(\beta=0.194)$, and marital status (unmarried) is related to women's $(\beta=-0.111)$. The change in $\mathrm{R}^{2}$ from Equation 1 to Equation 2 for men $(0.049)$ and women (0.018) are both significant. 
Table 1a. Men's self-reported depression symptoms regressed on criminal victimisation, controlling for demographic characteristics (Equation 2), fear of crime (Equation 3), protection (Equation 4)

\begin{tabular}{|c|c|c|c|c|c|c|c|c|}
\hline \multirow[b]{2}{*}{ Variable } & \multicolumn{2}{|c|}{ Equation 1} & \multicolumn{2}{|c|}{ Equation 2} & \multicolumn{2}{|c|}{ Equation 3} & \multicolumn{2}{|c|}{ Equation 4} \\
\hline & $\mathrm{b}$ & $\beta$ & $\mathrm{b}$ & $\beta$ & $\mathrm{b}$ & $\beta$ & $\mathrm{b}$ & $\beta$ \\
\hline Victimisation & $\begin{array}{c}1.506^{* *} \\
(0.439)\end{array}$ & 0.147 & $\begin{array}{l}1.463^{* *} \\
(0.445)\end{array}$ & 0.143 & $\begin{array}{l}1.322^{\star *} \\
(0.444)\end{array}$ & 0.129 & $\begin{array}{c}1.373^{* *} \\
(0.448)\end{array}$ & 0.134 \\
\hline \multicolumn{9}{|c|}{ Demographic Characteristics } \\
\hline Age & & & $\begin{array}{c}0.082^{\star \star *} \\
(0.018)\end{array}$ & 0.194 & $\begin{array}{c}0.077^{\star \star *} \\
(0.018)\end{array}$ & 0.181 & $\begin{array}{c}0.076^{* * *} \\
(0.018)\end{array}$ & 0.179 \\
\hline Education & & & $\begin{array}{l}-0.319 \\
(0.186)\end{array}$ & -0.075 & $\begin{array}{l}-0.338 \\
(0.185)\end{array}$ & -0.079 & $\begin{array}{l}-0.305 \\
(0.189)\end{array}$ & -0.071 \\
\hline Marital Status & & & $\begin{array}{l}-1.188 \\
(1.259)\end{array}$ & -0.040 & $\begin{array}{l}-1.116 \\
(1.251)\end{array}$ & -0.037 & $\begin{array}{l}-1.130 \\
(1.251)\end{array}$ & -0.038 \\
\hline Residence & & & $\begin{array}{c}0.190 \\
(0.435)\end{array}$ & 0.019 & $\begin{array}{l}-0.033 \\
(0.439)\end{array}$ & -0.003 & $\begin{array}{c}0.031 \\
(0.445)\end{array}$ & 0.003 \\
\hline Income & & & $\begin{array}{l}-0.146 \\
(0.198)\end{array}$ & -0.031 & $\begin{array}{l}-0.135 \\
(0.197)\end{array}$ & -0.029 & $\begin{array}{l}-0.131 \\
(0.197)\end{array}$ & -0.028 \\
\hline Fear of Crime & & & & & $\begin{array}{c}0.824^{* *} \\
(0.290)\end{array}$ & 0.123 & $\begin{array}{c}0.871^{* *} \\
(0.294)\end{array}$ & 0.131 \\
\hline Protection & & & & & & & $\begin{array}{l}-0.366 \\
(0.404)\end{array}$ & -0.041 \\
\hline Constant & $4.161^{* * *}$ & & 4.338 & & 4.135 & & 4.112 & \\
\hline $\mathrm{R}^{2}$ & 0.0022 & & 0.0071 & & 0.085 & & 0.086 & \\
\hline $\mathrm{R}^{2}$ Change & - & & $0.049^{* * *}$ & & $0.014^{* *}$ & & 0.001 & \\
\hline
\end{tabular}

${ }^{*} \mathrm{p} \leq 0.05^{* *} \mathrm{p} \leq 0.01{ }^{* * *} \mathrm{p} \leq 0.001$ (two-tailed tests)

Note: $\quad \mathrm{N}=535 ; \mathrm{b}=$ unstandardised regression coefficient with standard error in parentheses; $\beta=$ standardised regression coefficient.

Equation 3 (Tables 1 and 2) adds 'fear of crime'. As expected, fear of crime is positively related to men's depressive symptoms $(\beta=0.123)$. Criminal victimisation remains related to men's depressive symptoms in Equation $3(\beta=0.129)$, and fear of crime is also related to women's depressive symptoms in Equation $3(\beta=0.094)$. The changes in $\mathrm{R}^{2}$ for men (0.014) and women (0.008) are both significant.

Equation 4 (Tables 1 and 2) adds 'protection from criminal victimisation'. Protection is not, however, related to men's and women's depressive symptoms $(\beta=-0.041$ and -0.040 respectively). Criminal victimisation remains related to men's depressive symptoms $(\beta=0.134)$, as does fear of crime $(\beta=0.131)$. For women, fear of crime also remains related to depressive symptoms $(\beta=0.099)$. The changes in $\mathrm{R}^{2}$ for both men and women (0.001) are insignificant. 
Table 1b. Men's self-reported depression symptoms regressed on criminal victimisation, controlling for avoidance (Equation 5), mastery (Equation 6), social support (Equation 7), and trust in government (Equation 8)

\begin{tabular}{|c|c|c|c|c|c|c|c|c|}
\hline \multirow[b]{2}{*}{ Variable } & \multicolumn{2}{|c|}{ Equation 5} & \multicolumn{2}{|c|}{ Equation 6} & \multicolumn{2}{|c|}{ Equation 7} & \multicolumn{2}{|c|}{ Equation 8} \\
\hline & $\mathrm{b}$ & $\beta$ & $\mathrm{b}$ & $\beta$ & $\mathrm{b}$ & $\beta$ & $\mathrm{b}$ & $\beta$ \\
\hline Victimisation & $\begin{array}{l}1.303^{* *} \\
(0.442)\end{array}$ & 0.127 & $\begin{array}{l}1.105^{* *} \\
(0.420)\end{array}$ & 0.108 & $\begin{array}{l}1.079^{\star *} \\
(0.414)\end{array}$ & 0.105 & $\begin{array}{c}1.076^{* *} \\
(0.414)\end{array}$ & 0.105 \\
\hline \multicolumn{9}{|c|}{ Demographic Characteristics } \\
\hline Age & $\begin{array}{l}0.067^{* \star *} \\
(0.018)\end{array}$ & 0.158 & $\begin{array}{l}0.054^{* *} \\
(0.017)\end{array}$ & 0.128 & $\begin{array}{c}0.042^{*} \\
(0.017)\end{array}$ & 0.100 & $\begin{array}{c}0.042^{*} \\
(0.017)\end{array}$ & 0.100 \\
\hline Education & $\begin{array}{l}-0.362 \\
(0.187)\end{array}$ & -0.085 & $\begin{array}{l}-0.144 \\
(0.179)\end{array}$ & -0.034 & $\begin{array}{l}-0.104 \\
(0.177)\end{array}$ & -0.024 & $\begin{array}{l}-0.105 \\
(0.177)\end{array}$ & -0.025 \\
\hline Marital Status & $\begin{array}{l}-1.013 \\
(1.234)\end{array}$ & -0.034 & $\begin{array}{l}-1.742 \\
(1.174)\end{array}$ & -0.058 & $\begin{array}{l}-1.595 \\
(1.156)\end{array}$ & -0.053 & $\begin{array}{l}-1.587 \\
(1.157)\end{array}$ & -0.053 \\
\hline Residence & $\begin{array}{l}-0.052 \\
(0.438)\end{array}$ & -0.001 & $\begin{array}{c}0.248 \\
(0.417)\end{array}$ & 0.025 & $\begin{array}{c}0.197 \\
(0.411)\end{array}$ & 0.020 & $\begin{array}{c}0.198 \\
(0.411)\end{array}$ & 0.020 \\
\hline Income & $\begin{array}{l}-0.159 \\
(0.194)\end{array}$ & -0.034 & $\begin{array}{l}-0.102 \\
(0.184)\end{array}$ & -0.022 & $\begin{array}{l}-0.112 \\
(0.182)\end{array}$ & -0.024 & $\begin{array}{l}-0.110 \\
(0.182)\end{array}$ & -0.024 \\
\hline Fear of Crime & $\begin{array}{c}0.305 \\
(0.323)\end{array}$ & 0.046 & $\begin{array}{c}0.110 \\
(0.308)\end{array}$ & 0.016 & $\begin{array}{c}0.262 \\
(0.305)\end{array}$ & 0.039 & $\begin{array}{c}0.248 \\
(0.307)\end{array}$ & 0.037 \\
\hline Protection & $\begin{array}{l}-0.532 \\
(0.401)\end{array}$ & -0.060 & $\begin{array}{l}-0.495 \\
(0.380)\end{array}$ & -0.056 & $\begin{array}{l}-0.500 \\
(0.374)\end{array}$ & -0.056 & $\begin{array}{l}-0.504 \\
(0.375)\end{array}$ & -0.057 \\
\hline Avoidance & $\begin{array}{l}1.570^{\star * *} \\
(0.395)\end{array}$ & 0.192 & $\begin{array}{l}1.467^{* * *} \\
(0.375)\end{array}$ & 0.180 & $\begin{array}{l}1.411^{\star * *} \\
(0.370)\end{array}$ & 0.173 & $\begin{array}{l}1.401^{\text {*** }} \\
(0.370)\end{array}$ & 0.172 \\
\hline Mastery & & & $\begin{array}{l}-0.401^{* * *} \\
(0.052)\end{array}$ & -0.313 & $\begin{array}{l}-0.343^{* * *} \\
(0.053)\end{array}$ & -0.268 & $\begin{array}{l}-0.340^{* * *} \\
(0.053)\end{array}$ & -0.265 \\
\hline Social Support & & & & & $\begin{array}{l}-0.182^{* * *} \\
(0.044)\end{array}$ & -0.170 & $\begin{array}{l}-0.181^{* * *} \\
(0.044)\end{array}$ & -0.169 \\
\hline Trust in Govern & nent & & & & & & $\begin{array}{l}-0.088 \\
(0.196)\end{array}$ & -0.018 \\
\hline Constant & 4.514 & & $15.760^{* * *}$ & & $21.135^{* * *}$ & & $21.270^{* * *}$ & \\
\hline $\mathrm{R}^{2}$ & 0.113 & & 0.204 & & 0.230 & & 0.230 & \\
\hline $\mathrm{R}^{2}$ Change & $0.027^{* \star *}$ & & $0.092^{* * *}$ & & $0.025^{* * *}$ & & 0.000 & \\
\hline
\end{tabular}

${ }^{*} \mathrm{p} \leq 0.05^{* *} \mathrm{p} \leq 0.01^{* * *} \mathrm{p} \leq 0.001$ (two-tailed tests)

Note: $\quad \mathrm{N}=535 ; \mathrm{b}=$ unstandardised regression coefficient with standard error in parentheses; $\beta=$ standardised regression coefficient.

Avoidance is related to men's depressive symptoms in Equation $5(\beta=0.192)$. Criminal victimisation remains related to men's depressive symptoms $(\beta=0.127)$, but fear of crime is no longer significantly related to their depression $(\beta=0.046)$. Avoidance mediates the relationship between men's fear of crime and depression. For women, avoidance is not significantly related to depressive symptoms $(\beta=0.032)$, but fear of crime remains related to their depression $(\beta=0.088)$. The change in $\mathrm{R}^{2}$ for men $(0.027)$ is significant, but the change in $\mathrm{R}^{2}$ for women $(0.001)$ is not.

As expected, mastery is related to men's depressive symptoms in Equation 6 ( $\beta=$ $-0.313)$, and criminal victimisation remains significantly related to their depression $(\beta=$ $0.108)$, as does avoidance $(\beta=0.180)$. Mastery is also related to women's depressive symptoms $(\beta=-0.375)$, while fear of crime is no longer significantly related to women's 
depressive symptoms $(\beta=0.066)$. Mastery mediates the relationship between women's fear of crime and depressive symptoms. The change in $\mathrm{R}^{2}$ for men $(0.092)$ and women (0.137) are both significant.

Table 2a. Women's self-reported depression symptoms regressed on criminal victimisation, controlling for demographic characteristics (Equation 2), fear of crime (Equation 3), protection (Equation 4)

\begin{tabular}{|c|c|c|c|c|c|c|c|c|}
\hline \multirow[b]{2}{*}{ Variable } & \multicolumn{2}{|c|}{ Equation 1} & \multicolumn{2}{|c|}{ Equation 2} & \multicolumn{2}{|c|}{ Equation 3} & \multicolumn{2}{|c|}{ Equation 4} \\
\hline & $\mathrm{b}$ & $\beta$ & $\mathrm{b}$ & $\beta$ & $\mathrm{b}$ & $\beta$ & $\mathrm{b}$ & $\beta$ \\
\hline Victimisation & $\begin{array}{c}0.906 \\
(0.553)\end{array}$ & 0.065 & $\begin{array}{c}0.827 \\
(0.570)\end{array}$ & 0.059 & $\begin{array}{c}0.685 \\
(0.571)\end{array}$ & 0.049 & $\begin{array}{c}0.757 \\
(0.576)\end{array}$ & 0.054 \\
\hline \multicolumn{9}{|c|}{ Demographic Characteristics } \\
\hline Age & & & $\begin{array}{c}0.035 \\
(0.023)\end{array}$ & 0.062 & $\begin{array}{c}0.034 \\
(0.023)\end{array}$ & 0.061 & $\begin{array}{c}0.035 \\
(0.023)\end{array}$ & 0.063 \\
\hline Education & & & $\begin{array}{c}0.111 \\
(0.286)\end{array}$ & 0.016 & $\begin{array}{c}0.089 \\
(0.286)\end{array}$ & 0.013 & $\begin{array}{c}0.083 \\
(0.286)\end{array}$ & 0.012 \\
\hline Marital Status & & & $\begin{array}{c}1.745^{* *} \\
(0.638)\end{array}$ & -0.111 & $\begin{array}{l}-1.810^{* *} \\
(0.637)\end{array}$ & -0.115 & $\begin{array}{l}-1.749^{* *} \\
(0.640)\end{array}$ & -0.111 \\
\hline Residence & & & $\begin{array}{l}-0.276 \\
(0.526)\end{array}$ & -0.022 & $\begin{array}{l}-0.471 \\
(0.531)\end{array}$ & -0.037 & $\begin{array}{l}-0.377 \\
(0.539)\end{array}$ & -0.030 \\
\hline Income & & & $\begin{array}{l}-0.169 \\
(0.199)\end{array}$ & -0.034 & $\begin{array}{l}-0.164 \\
(0.199)\end{array}$ & -0.034 & $\begin{array}{l}-0.156 \\
(0.199)\end{array}$ & -0.032 \\
\hline Fear of Crime & & & & & $\begin{array}{c}0.883^{*} \\
(0.379)\end{array}$ & 0.094 & $\begin{array}{c}0.933^{*} \\
(0.383)\end{array}$ & 0.099 \\
\hline Protection & & & & & & & $\begin{array}{l}-0.541 \\
(0.563)\end{array}$ & -0.040 \\
\hline Constant & $6.797^{\star \star \star}$ & & $8.904^{* * *}$ & & $8.212^{* \star *}$ & & $8.060^{* * *}$ & \\
\hline $\mathrm{R}^{2}$ & 0.004 & & 0.022 & & 0.030 & & 0.031 & \\
\hline $\mathrm{R}^{2}$ Change & & & $0.018^{*}$ & & $0.008^{*}$ & & 0.001 & \\
\hline
\end{tabular}

${ }^{*} \mathrm{p} \leq 0.05^{* *} \mathrm{p} \leq 0.01^{* * *} \mathrm{p} \leq 0.001$ (two-tailed tests)

Note: $\quad \mathrm{N}=639 ; \mathrm{b}=$ unstandardised regression coefficient with standard error in parentheses; $\beta=$ standardised regression coefficient.

Social support is related to men's depressive symptoms in Equation $7(\beta=-0.170)$. Criminal victimisation remains related to men's depression $(\beta=0.105)$, as do avoidance $(\beta=0.173)$ and mastery $(\beta=-0.268)$. Social support is also significantly related to women's depression in Equation $7(\beta=-0.127)$, as is mastery $(\beta=-0.342)$. The change in $\mathrm{R}^{2}$ for men (0.025) and women (0.015) are both significant.

Equation 8 (Tables 1 and 2) adds trust in government to the explanation of depression. Trust in government is not significantly related to men's or women's depressive symptoms $(\beta=-0.018$ and -0.006$)$. Criminal victimisation remains related to men's depressive symptoms $(\beta=0.105)$, as do avoidance $(\beta=0.172)$, mastery $(\beta=-0.265)$, and social support $(\beta=-0.169)$. Criminal victimisation and fear of crime continue to be unrelated to women's depression $(\beta=0.049$ and 0.077$)$, but mastery and social support are related $(\beta=-0.342$ and -0.127$)$. Equation 8 explains $23 \%$ of the variance in men's depressive symptoms and $18.4 \%$ in women's. No significant changes in $\mathrm{R}^{2}$ occur for men or women. 
Table 2b. Women's self-reported depression symptoms regressed on criminal victimisation, controlling for avoidance (Equation 5), mastery (Equation 6), social support (Equation 7), and trust in government (Equation 8)

\begin{tabular}{|c|c|c|c|c|c|c|c|c|}
\hline \multirow[b]{2}{*}{ Variable } & \multicolumn{2}{|c|}{ Equation 5} & \multicolumn{2}{|c|}{ Equation 6} & \multicolumn{2}{|c|}{ Equation 7} & \multicolumn{2}{|c|}{ Equation 8} \\
\hline & $\mathrm{b}$ & $\beta$ & $\mathrm{b}$ & $\beta$ & $\mathrm{b}$ & $\beta$ & $\mathrm{b}$ & $\beta$ \\
\hline Victimisation & $\begin{array}{c}0.758 \\
(0.576)\end{array}$ & 0.054 & $\begin{array}{c}0.646 \\
(0.534)\end{array}$ & 0.046 & $\begin{array}{c}0.682 \\
(0.530)\end{array}$ & 0.049 & $\begin{array}{c}0.683 \\
(0.530)\end{array}$ & 0.049 \\
\hline \multicolumn{9}{|c|}{ Demographic Characteristics } \\
\hline Age & $\begin{array}{c}0.033 \\
(0.023)\end{array}$ & 0.060 & $\begin{array}{c}0.030 \\
(0.021)\end{array}$ & 0.054 & $\begin{array}{c}0.023 \\
(0.021)\end{array}$ & 0.042 & $\begin{array}{c}0.023 \\
(0.021)\end{array}$ & 0.042 \\
\hline Education & $\begin{array}{c}0.080 \\
(0.286)\end{array}$ & 0.012 & $\begin{array}{c}0.230 \\
(0.265)\end{array}$ & 0.033 & $\begin{array}{c}0.241 \\
(0.263)\end{array}$ & 0.035 & $\begin{array}{c}0.240 \\
(0.264)\end{array}$ & 0.035 \\
\hline Marital Status & $\begin{array}{l}-1.736^{* *} \\
(0.640)\end{array}$ & -0.110 & $\begin{array}{l}-1.133 \\
(0.597)\end{array}$ & -0.072 & $\begin{array}{l}-1.161^{*} \\
(0.592)\end{array}$ & -0.074 & $\begin{array}{l}-1.161^{*} \\
(0.593)\end{array}$ & -0.073 \\
\hline Residence & $\begin{array}{l}-0.408 \\
(0.541)\end{array}$ & -0.032 & $\begin{array}{l}-0.331 \\
(0.502)\end{array}$ & -0.026 & $\begin{array}{l}-0.265 \\
(0.498)\end{array}$ & -0.021 & $\begin{array}{l}-0.267 \\
(0.499)\end{array}$ & 0.021 \\
\hline Income & $\begin{array}{l}-0.153 \\
(0.199)\end{array}$ & -0.031 & $\begin{array}{l}-0.110 \\
(0.185)\end{array}$ & -0.023 & $\begin{array}{l}-0.081 \\
(0.183)\end{array}$ & -0.016 & $\begin{array}{l}-0.081 \\
(0.184)\end{array}$ & -0.017 \\
\hline Fear of Crime & $\begin{array}{c}0.827^{*} \\
(0.408)\end{array}$ & 0.088 & $\begin{array}{c}0.622 \\
(0.378)\end{array}$ & 0.066 & $\begin{array}{c}0.712 \\
(0.376)\end{array}$ & 0.075 & $\begin{array}{c}0.722 \\
(0.382)\end{array}$ & 0.077 \\
\hline Protection & $\begin{array}{l}-0.565 \\
(0.564)\end{array}$ & -0.041 & $\begin{array}{l}-0.424 \\
(0.523)\end{array}$ & -0.031 & $\begin{array}{l}-0.545 \\
(0.521)\end{array}$ & -0.040 & $\begin{array}{l}-0.538 \\
(0.523)\end{array}$ & -0.039 \\
\hline Avoidance & $\begin{array}{c}0.266 \\
(0.353)\end{array}$ & 0.032 & $\begin{array}{c}0.120 \\
(0.327)\end{array}$ & 0.015 & $\begin{array}{c}0.079 \\
(0.325)\end{array}$ & 0.010 & $\begin{array}{c}0.083 \\
(0.326)\end{array}$ & 0.010 \\
\hline Mastery & & & $\begin{array}{l}-0.612^{* * *} \\
(0.060)\end{array}$ & -0.375 & $\begin{array}{l}-0.559^{\star * *} \\
(0.062)\end{array}$ & -0.342 & $\begin{array}{l}-0.559^{* * *} \\
(0.062)\end{array}$ & -0.342 \\
\hline Social Support & & & & & $\begin{array}{l}-0.177^{* * *} \\
(0.053)\end{array}$ & -0.127 & $\begin{array}{l}-0.177^{* * *} \\
(0.053)\end{array}$ & -0.127 \\
\hline Trust in Govern & nent & & & & & & $\begin{array}{l}-0.034 \\
(0.243)\end{array}$ & -0.006 \\
\hline Constant & $8.065^{* * *}$ & & $21.659^{\star \star *}$ & & $27.086^{* * *}$ & & $26.970^{* * *}$ & \\
\hline $\mathrm{R}^{2}$ & 0.032 & & 0.169 & & 0.184 & & 0.184 & \\
\hline $\mathrm{R}^{2}$ Change & 0.001 & & $0.137^{* * *}$ & & $0.015^{* * *}$ & & 0.000 & \\
\hline
\end{tabular}

${ }^{*} \mathrm{p} \leq 0.05^{* *} \mathrm{p} \leq 0.01{ }^{* * *} \mathrm{p} \leq 0.001$ (two-tailed tests)

Note: $\quad \mathrm{N}=639 ; \mathrm{b}=$ unstandardised regression coefficient with standard error in parentheses; $\beta=$ standardised regression coefficient.

\section{Discussion}

There was a direct relation between men's criminal victimisation and depression through all of the equations. This relationship was reduced with additional equations, but remained significant. Criminal victimisation was not related to women's depression. For Czech men at least, it appears that criminal victimisation is an undesirable experience that leads to depression. It may be more of a gender identity threatening stressor for men than it is for women. Assuming that higher resistance to victimisation is typically a major part of men's masculine identities (and typically not a major part of women's feminine identities), being victimised could be perceived by male victims as their inability to meet the expectations of their gender roles - which could then lead to unfavourable selfevaluations and increased depression [Thoits 1991; Wheaton 1996]. 
Fear of crime was also related to men's depression. However, it did not mediate between men's criminal victimisation and depression. Perhaps criminal victimisation presents such a threat for Czech men that it needs little subjective appraisal to produce distress. Fear of crime was also related to women's depression. It appears that the more Czech men and women are afraid of being the victim of a crime, regardless of whether or not they have been victimised, the higher their risk of depression becomes.

Taking protective action was not related to men's and women's depression. This may be due to the use of a protection from property crime measure. This analysis attempted to find a crossover effect from property protection to protection from physical harm, but no such effect was detected. Avoidance was related to men's depression, by contrast, and it added to their depression. Avoidance did not mediate between men's criminal victimisation and depression, but it significantly added to the explanation of Czech men's depression. Avoidance may not have mediated between Czech men's criminal victimisation and depression because they were not able to avoid situations that render them vulnerable to future victimisation, perhaps due to a lack of flexibility in work or other role demands. However, avoidance was found to mediate between men's fear of crime and depression. Czech men who responded to their fear of crime with avoidance may have been more adversely affected by the resulting disruptions of daily life and restrictions on personal freedoms. On the other hand, avoidance was not significantly related to women's depression. Perhaps women are more used to using avoidance-coping strategies in dealing with the threat of criminal victimisation. It is typical for American women to incorporate avoidance of higher crime-risk situations and activities into their daily lives [Karmen 1984]. Perhaps Czech women have similar routines and suffer relatively little distress from them [Hraba et al. 1999].

For men, mastery was related to decreased depression. For women, mastery was also related to decreased depression, and it mediated the relationship between women's fear of crime and depression. People who perceive a high sense of mastery may generally be less depressed because of its enhancing effect on self-confidence, self-esteem and happiness. Perhaps Czech women, even if fearful of crime, become less depressed from this fear because their sense of personal control lowers their perceived risk of being victimised. Perhaps mastery did not mediate between criminal victimisation and depression because being victimised leads to the interpretation that one does not have total mastery over one's life. Thus a sense of mastery may have been neutralised, and criminal victimisation was allowed to have a more direct impact on well-being.

For both men and women, social support was significantly related to decreased depression. Although social support did not mediate between criminal victimisation and depression, it significantly added to the explanation of depression. People in mutually supportive relationships may generally be less depressed because they continually serve as resources for each others' self-actualisation. It appears that depression was reduced by receiving interpersonal support, which is consistent with stress-distress studies examining the distress-reducing effects of social support. Perhaps social support did not mediate the relation between men's victimisation and depression because social support used to cope with criminal victimisation is selective and specific, whereas the measure of social support used in this analysis is a general one. For example, after experiencing criminal victimisation, the victim may seek the support of only significant others such as spouses or parents, and this support typically involves reassurances rather than tangible aid. 
Trust in government was not significantly related to depression for men or women. It was expected that the more confidence Czechs had in their government to prevent future criminal victimisation, the less they would become depressed. Perhaps one's fear of crime and depression due to criminal victimisation are more influenced by micro-level social factors such as the quality of the neighbourhood, the perceived effectiveness of local police, and the quality of interpersonal relationships within the community rather than the qualities of large-scale government.

Criminal victimisation, fear of crime, and behavioural reactions to crime were patterned by the controls. Among Czech men, criminal victimisation was higher for the higher educated, the unmarried, and those living in urban areas. Among women, criminal victimisation was higher for those living in urban areas. Men's fear of crime increased with age and education level and was higher for those living in urban areas. Women's fear of crime was higher for those living in urban areas. More protective action was taken by higher educated men, and urban men and women. Avoidance of crime was taken more by older men and women, higher educated men, and urban men and women. Further sex differences are also worth noting. A higher proportion of men reported victimisation than women, but women's fear of crime was twice as high as men's. These patterns indicate a sociological significance to this social psychological study. Criminal victimisation, fear of crime, and their effects on well-being vary by residence, age, education, and coping, as well as sex.

An exact causal ordering cannot be inferred from this analysis. For example, it is possible that respondents could have taken action or been afraid of crime prior to experiencing any victimisation. Still, this analysis was able to detect that male victims were more likely to report depressive symptoms, and that avoidance of crime appeared to amplify men's depression. The fact that these trends did not hold true for women presents an interesting sex difference in regard to responding to criminal victimisation. Fear of crime was related to depression for both men and women, but women's mastery appeared to suppress this relationship, while men's avoidance appeared to amplify it.

LeE Michael JohnSON is a Ph.D. candidate in the Department of Sociology at Iowa State University. His research interests include the impact of criminal victimisation on mental health, victimisation and attribution, the effects of reactions to crime, and juvenile delinquency.

JOSEPH HRABA is professor of Sociology at Iowa State University. His research interests include the Czech transition, its impact on health, and ethnic attitudes in various parts of the world. He has recently published in American, British, Czech and Russian journals.

FREDERICK O. LORENZ is professor in the Department of Sociology at the Institute for Social and Behavioral Research at Iowa State University. His research interests have focused on the impact of crime, and delinquency, and also on various apects of change within the framework of the modern family.

\section{References}

Aneshensel, Carol S. 1992. "Social Stress: Theory and Research." Annual Review of Sociology 18: $15-38$.

Buriánek, Jiří 1994. "The Relatively Minimal-Anomie Czech Transition: The Case of Prague." Czech Sociological Review 2: 229-247.

Coyne, James C., Geraldine Downey 1991. "Social Factors and Psychopathology: Stress, Social Support, and Coping Processes." Annual Review of Psychology 42: 401-425. 
Derogatis, L. R. 1983. SCL-90-R: Administration, Scoring and Procedures Manual II. 2nd Edition. Towson, MD: Psychometric Research.

DuBow, Fredric, Edward McCabe, Gail Kaplan 1979. Reactions to Crime: A Critical Review of the Literature. Washington, DC: National Institute of Law Enforcement and Criminal Justice; US Government Printing Office.

Elder, Glen H., Jr. 1974. Children of the Great Depression. Chicago: University of Chicago Press.

Elder, Glen H., Jr., Elizabeth B. Robertson, Monika Ardelt 1994. "Families Under Economic Pressure." Pp. 79-103 in Families in Troubled Times: Adapting to Change In Rural America, ed. by Rand D. Conger and Glen H. Elder, Jr. (in Collaboration with Frederick O. Lorenz, Ron L. Simons, and Les B. Whitbeck). New York: Aldine.

Ensel, Walter M., Nan Lin 1991. "The Life Stress Paradigm and Psychological Distress.” Journal of Health and Social Behavior 32: 321-341.

Ferraro, Kenneth F. 1995. Fear of Crime: Interpreting Victimization Risk. Albany, NY: State University of New York Press.

Friedemann, Marie Luise, Adele A. Webb 1995. "Family Health and Mental Health Six Years After Economic Stress and Unemployment." Issues in Mental Health Nursing 16(1): 51-66.

Garofalo, James 1981. "The Fear of Crime: Causes and Consequences." The Journal of Criminal Law and Criminology 72(2): 839-857.

Giles-Sims, Jean 1984. "A Multivariate Analysis of Perceived Likelihood of Victimization and Degree of Worry About Crime Among Older People.” Victimology 9(2): 222-233.

Hraba, Joseph, Frederick O. Lorenz, Gang Lee, Zdeňka Pechačová 1994. "Economic Change, Inequality and Distress in the Czech Republic." Czech Sociological Review 2: 173-185.

Hraba, Joseph, Frederick O. Lorenz, Gang Lee 1996. "Gender and Well-Being in the Czech Republic." Sex Roles 34: 517-533.

Hraba, Joseph, Frederick O. Lorenz, Zdeňka Pechačová 1997. “Age and Depression in the PostCommunist Czech Republic.” Research on Aging 19(4): 442-461.

Hraba, Joseph, Wan-Ning Bao, Frederick O. Lorenz, and Zdeňka Pechačová 1998. "Perceived Risk of Crime in the Czech Republic." Journal of Research in Crime and Delinquency 35(2): 225-242.

Hraba, Joseph, Frederick O. Lorenz, Zdeňka Pechačová, Wan-Ning Bao 1999. "Criminal Victimization and Distress in the Czech Republic.” Journal of Interpersonal Violence 14: 1030-1054.

Karmen, Andrew 1984. Crime Victims. Belmont, CA: Wadsworth, Inc.

Kilpatrick, Dean G., Connie L. Best, Lois J. Veronen, Angelynne E. Amick, Lorenz A. Villeponteaux, Gary A. Ruff 1985. "Mental Health Correlates of Criminal Victimization: A Random Community Survey.” Journal of Consulting and Clinical Psychology 53(6): 866-873.

LaFree, Gary, Kriss A. Drass 1996. "The Effect of Changes in Interracial Income Inequality and Educational Attainment on Changes in Arrest Rates for African Americans and Whites, 1957 to 1990.” American Sociological Review 61: 614-634.

LaGrange, Randy L., Kenneth F. Ferraro 1989. “Assessing Age and Gender Differences in Perceived Risk and Fear of Crime." Criminology 27(4): 697-719.

Liska, Allen E., Barbara D. Warner 1991. "Functions of Crime: A Paradoxical Process." American Journal of Sociology 96: 1441-1463.

Lorenz, Frederick O., Joseph Hraba, Rand D. Conger, Zdeňka Pechačová 1996. "Economic Change and Change in Well-being in the Czech Republic, with Comparisons to Married Women in the United States." Czech Sociological Review 4: 43-62.

Matějů, Petr, Blanka Řeháková 1996. "Education as a Strategy for Life Success in the Postcommunist Transformation: The Case of the Czech Republic." Comparative Education Review 40(2): 158-176. 
Mawby, R. I., S. Walkate 1994. Critical Victimology: International Perspectives. London: Sage.

Miethe, Terance D., Gary R. Lee 1984. "Fear of Crime Among Older People: A Reassessment of the Predictive Power of Crime-Related Factors." The Sociological Quarterly 25: 397-415.

Mirowsky, John, Catherine E. Ross 1989. Social Causes of Psychological Distress. New York: Aldine de Gruyter.

Musil, Jiří 1992. “Czechoslovakia in the Middle of Transition.” Daedalus 121: 175-195.

Norris, Fran H., Krzystof Kaniasty 1994. "Psychological Distress Following Criminal Victimization in the General population: Cross-Sectional, Longitudinal, and Prospective Analyses." Journal of Consulting and Clinical Psychology 62(1): 111-123.

Pearlin, Leonard I. 1989. "The Sociological Study of Stress." Journal of Health and Social Behavior 30: 241-256.

Pearlin, Leonard I., Morton A. Lieberman, Elizabeth G. Menaghan, Joseph T. Mullan 1981 “The Stress Process." Journal of Health and Social Behavior 22: 337-356.

Proulx, Jocelyn, Catherine Koverola, Anne Fedorowicz, Michael Kral 1995. "Coping Strategies as Predictors of Distress in Survivors of Single and Multiple Sexual Victimization and Nonvictimized Controls." Journal of Applied Social Psychology 25(16): 1464-1483.

Rondinelli, Dennis A. 1994. "Privatization and Economic Reform in Central Europe: Experience of the Early Transition Period." Pp. 1-40 in Privatization And Economic Reform in Central Europe: The Changing Business Climate, ed. by Dennis A. Rondinelli. Westport, CT: Quorum Books.

Rose, Richard 1994. "Postcommunism and the Problem of Trust." Journal of Democracy 5(3): 1830.

Ross, Catherine E. 1993. "Fear of Victimization and Health." Journal of Quantitative Criminology 9(2): 159-175.

Roundtree, Pamela Wilcox, Kenneth C. Land 1996. "Perceived Risk Versus Fear of Crime: Empirical Evidence of Conceptually Distinct Reactions in Survey Data." Social Forces 74(4): 1353-1376.

Sarason, Irwin G., Gregory R. Pierce, Barbara R. Sarason 1994. "General and Specific Perceptions of Social Support.” Pp. 151-177 in Stress and Mental Health: Contemporary Issues and Prospects for the Future, ed. by William R. Avison and Ian H. Gotlib. New York: Plenum Press.

Siemaszko, Andrzej 1993. "Central and Eastern European Victimisation Rates: To Compare or Not To Compare?” Pp. 87-92 in Understanding Crime: Experiences of Crime and Crime Control, ed. by Anna Alvazzi del Frate, Uglijesa Zvekic, and Jan J. M. van Dijk. The Hague: Ministry of Justice, The Netherlands.

Taylor, Ralph B., Margaret Hale 1986. "Testing Alternative Models of Fear of Crime.” Journal of Criminal Law and Criminology 77(1): 151-189.

Taylor, S. E., L. G. Aspinwall 1996. "Mediating and Moderating Processes in Psychosocial Stress: Appraisal, Coping, Resistance, and Vulnerability.” Pp. 71-110 in Psychosocial Stress: Perspectives on Structure, Theory, Life-Course, and Methods, ed. by H. B. Kaplan. San Diego, CA: Academic Press.

Thoits, Peggy A. 1991. “On Merging Identity Theory and Stress Research.” Social Psychology Quarterly 54: 101-112.

Thompson, Martie P., Fran H. Norris 1992. "Crime, Social Status, and Alienation." American Journal of Community Psychology 20(1): 97-119.

Turner, R. Jay, Patricia Roszell 1994. "Psychosocial Resources and the Stress Process.” Pp. 179210 in Stress and Mental Health: Contemporary Issues and Prospects for the Future, ed. by William R. Avison and Ian H. Gotlib. New York: Plenum Press. 
Turner, R. Jay, Blair Wheaton, Donald A. Lloyd 1995. "The Epidemiology of Social Stress." American Sociological Review 60: 104-125.

Valkova, Jana 1993. "Czechoslovakia." Pp. 493-498 in Understanding Crime: Experiences of Crime and Crime Control, ed. by Anna Alvazzi del Frate, Uglijesa Zvekic, and Jan J. M. van Dijk. The Hague: Ministry of Justice, The Netherlands.

Večerník, Jiří 1995. "Changing Earnings Distribution in the Czech Republic: Survey Evidence from 1988-1994." Economics of Transition 3(3): 355-371.

Večerník, Jiří 1996a. "Earnings Disparities in the Czech Republic: The History of Equalisation." Czech Sociological Review 4(2): 211-222.

Večerník, Jiří 1996b. Markets and People: The Czech Reform Experience in Comparative Perspective. Aldershot, UK: Avebury.

Warr, Mark 1994. "Public Perceptions and Reactions to Violent Offending and Victimization." Pp. 1-66 in Understanding and Preventing Violence, Volume 4: Consequences and Control, ed. by Albert J. Reiss, Jr. and Jeffery A. Roth. Washington, DC: National Academy Press.

Wheaton, Blair 1996. "The Domains and Boundaries of Stress Concepts." Pp. 29-70 in Psychosocial Stress: Perspectives on Structure, Theory, Life-Course, and Methods, ed. by Howard B. Kaplan. San Diego, CA: Academic Press.

Williams, David R. 1990. "Socioeconomic Differentials in Health: A Review and Redirection." Social Psychology Quarterly 53(2): 81-99. 